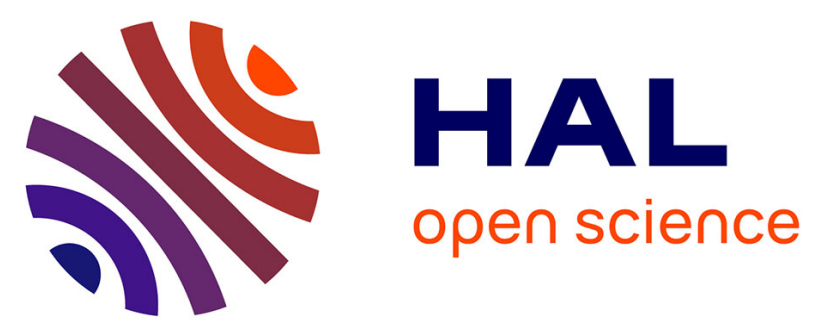

\title{
Allelic genotyping reveals a hierarchy of genomic alterations in mantle cell lymphoma associated to cell proliferation
}

G. Hutter, M. Scheubner, G. Ott, Y. Zimmermann, K. Hübler, S. Roth, S. Stilgenbauer, J. Kalla, H. Stöcklein, W. Hiddemann, et al.

\section{To cite this version:}

G. Hutter, M. Scheubner, G. Ott, Y. Zimmermann, K. Hübler, et al.. Allelic genotyping reveals a hierarchy of genomic alterations in mantle cell lymphoma associated to cell proliferation. Annals of Hematology, 2009, 88 (9), pp.821-828. 10.1007/s00277-008-0686-2 . hal-00535022

\section{HAL Id: hal-00535022 \\ https://hal.science/hal-00535022}

Submitted on 11 Nov 2010

HAL is a multi-disciplinary open access archive for the deposit and dissemination of scientific research documents, whether they are published or not. The documents may come from teaching and research institutions in France or abroad, or from public or private research centers.
L'archive ouverte pluridisciplinaire HAL, est destinée au dépôt et à la diffusion de documents scientifiques de niveau recherche, publiés ou non, émanant des établissements d'enseignement et de recherche français ou étrangers, des laboratoires publics ou privés. 


\title{
Allelic genotyping reveals a hierarchy of genomic alterations in mantle cell lymphoma associated to cell proliferation
}

\author{
G. Hutter • M. Scheubner • G. Ott • Y. Zimmermann • \\ K. Hübler • S. Roth $\cdot$ S. Stilgenbauer • J. Kalla • \\ H. Stöcklein • W. Hiddemann • M. Dreyling
}

Received: 11 February 2008 /Accepted: 18 December 2008 / Published online: 10 January 2009

(C) Springer-Verlag 2009

\begin{abstract}
Mantle cell lymphoma (MCL) is a distinct subentity of non-Hodgkin lymphoma, characterized by the chromosomal translocation $\mathrm{t}(11 ; 14)(\mathrm{q} 13 ; \mathrm{q} 32)$ leading to an overexpression of cyclin D1 in virtually all cases. However, additional cytogenetic aberrations are apparent in the vast majority of MCL. Applying LOH analysis in $52 \mathrm{MCL}$ patient samples, we confirmed frequent alterations in $9 \mathrm{p} 21$ $(28.6 \%)$ and $p 53(28.9 \%)$ but also detected allelic losses in $1 \mathrm{p} 21,9 \mathrm{q} 21,13 \mathrm{q} 13-14,13 \mathrm{q} 31-32,17 \mathrm{p} 13.1$, and $17 \mathrm{p} 13.3$ in $28-45 \%$ of cases and allelic gains in $3 \mathrm{q} 27-28$ and $19 \mathrm{p} 13.3$ in $14-22 \%$ of cases. In addition, losses in the $2 \mathrm{p} 23$ and
\end{abstract}

St. St. Landesstiftung Ba-Wü (Proteomics).

H. Stöcklein und J. Kalla are supported by the Graduiertenkolleg of the University of Wuerzburg.

This work was supported by the European Union: 6.FP, Translational research on promising predictive and prognostic markers: "European MCL Network" (contract no. 503351).

Electronic supplementary material The online version of this article (doi:10.1007/s00277-008-0686-2) contains supplementary material, which is available to authorized users.

G. Hutter $(\bowtie) \cdot$ M. Scheubner $\cdot$ Y. Zimmermann •

W. Hiddemann $\cdot$ M. Dreyling

Department of Medicine III,

University Hospital Grosshadern/LMU, CCG Leukemia,

Helmholtz Zentrum München,

German Research Center for Environmental Health,

Munich, Germany

e-mail: hutter@helmholtz-muenchen.de

G. Ott $\cdot$ K. Hübler $\cdot$ S. Roth $\cdot$ J. Kalla $\cdot$ H. Stöcklein

Institute of Pathology, University of Wuerzburg,

Wuerzburg, Germany

S. Stilgenbauer

Department of Internal Medicine III, University of Ulm,

Ulm, Germany 7q22-35 genomic regions not previously described to be altered in MCL were identified in up to $20 \%$ of cases. Applying multivariate analysis, a cluster of genomic aberrations including 1p21, 3q27, 7q22-36, 6p24, 9p21, $9 \mathrm{q} 31$, and $16 \mathrm{p} 12$ alterations was identified which was closely associated to cell proliferation as determined by Ki67 immunostaining. This proliferation-dependent network of oncogenic alterations complements the previously identified proliferation expression signature described by RNA expression profiling in MCL.

Keywords $\mathrm{MCL} \cdot \mathrm{LOH}$ analysis $\cdot$ Cell proliferation $\cdot 17 \mathrm{p} 13$

\section{Introduction}

Mantle cell lymphoma (MCL) has been recognized as a distinct subtype of malignant lymphoma in the current WHO Lymphoma classification system. It represents 6-9\% of malignant lymphomas and is characterized by distinctive immunophenotypic and genetic features $[13,26]$. The clinical outcome of mantle cell lymphoma is dismal, with a median survival time of only 3 years due to rapidly developing chemoresistance and frequent relapses [13]. However, a minority of patients survive up to 10 years, indicating the clinical and biological heterogeneity of MCL [39].

Morphologically, two subgroups of MCL have been recognized. The classical MCL is composed of small to medium-sized lymphoid cells with small, irregular nuclei and a relatively low proliferative index $[2,48]$. The blastoid variant is characterized by either pleomorphic or larger blast-like nuclei with a fine and dispersed chromatin and occasional small nucleoli. This variant displays a higher cell proliferation and a more aggressive clinical course than typical MCL [35]; [48]. Secondary transformations towards 
the blastoid variant forms have been observed in $26-70 \%$ of MCL patients. Genetically, MCL is characterized by the chromosomal translocation $\mathrm{t}(11 ; 14)(\mathrm{q} 13 ; \mathrm{q} 32)$, which corresponds to the juxtaposition of cyclinDl to the immunoglobulin heavy chain gene promoter and resulting in the constitutive overexpression of CyclinD1. Recently, it could be demonstrated that the proliferation gene expression signature is a central prognostic factor in MCL [39]. The expression profile of only four genes identified low risk patients with a median survival of up to 10 years. Another genetic signature distinguished $\mathrm{Ki}-67^{\text {high }}$ from $\mathrm{Ki}-67^{\text {low }}$ MCL and consisted of 32 genes involved in cellular processes, such as mitotic spindle formation, gene transcription and cell cycle regulation [16]. In addition, Katzenberger et al. show a closed correlation between the Ki67 index of tumor cells and survival in MCL [27].

Despite the fact that cyclinD1 has been identified as an important oncogene in various solid tumors, the transforming properties of cyclin D1 seem to be less efficient than other oncogenes [23]. Thus, in cyclin D1 transgenic animals mice the lymphomagenesis required the cooperation of other additional oncogenes, indicating that additional molecular alterations are necessary for the clinical development and progression of MCL [30].

Accordingly, secondary molecular alterations are frequently detected in MCL. Blastoid variants of MCL have a high incidence of $p 53$ gene mutations [20, 21], p16 $6^{I N K 4 a}$ deletions or hypermethylation $[14,25,36]$. In addition, shorter survival among MCL patients has been correlated with overexpression of $c$-myc [32] and a high cell proliferation index as measured by immunostaining of other proliferation-associated transcription factors [44]. Applying FISH analysis, a deletion of the 11q14-q24 chromosomal region including the ATM gene could be identified in $46 \%$ of MCL cases [45]. The detection of mutations of ATM in MCL patients suggested a potential susceptibility role in the tumorigenesis of MCL [42]. Another important tumor suppressor region on chromosomal band 13q14 was deleted in 70\% of MCL $[14,46]$.

Comparative genomic hybridization (CGH) and arraybased genomic analysis revealed amplifications in 3q, 7p, 8q, $12 \mathrm{q}, 18 \mathrm{q}, 9 \mathrm{q}$ and deletions in $6 \mathrm{q}, 1 \mathrm{p}, 11 \mathrm{q}, 10 \mathrm{p}, 17 \mathrm{p}, 9 \mathrm{p}$, and $13 q$ as frequent secondary genetic alterations $[1,5,19,28,41$, 44]. Those genetic alterations were more frequently found in blastoid than in classical MCL $[4,31]$.

Despite these important observations, little is known about the functional interaction of secondary genomic aberrations in MCL. To determine the impact of chromosomal imbalances on tumor cell proliferation, a comprehensive genomic allelotyping was performed in $52 \mathrm{MCL}$ patient samples (blastoid and classical) using 87 microsatellite-primers evenly distributed over the whole genome. Applying PCR-based LOH analysis, tumor DNA and normal control samples of individual patients were analyzed for deletions or amplifications of distinct genomic regions.

\section{Materials and methods}

Tumor samples Fifty-two MCL patients with a median age of 66.5 years were investigated in this retrospective study. All tumors were reviewed by a member of the European MCL Pathology panel (G.O.) and classified according to the criteria of the WHO lymphoma classification. Cyclin D1 overexpression or $\mathrm{t}(11 ; 14)(\mathrm{q} 13 ; \mathrm{q} 32)$ translocation were identified by Northern blot analysis or cytogenetic FISH analysis, respectively. Genomic DNA was extracted from formalin fixed tumor tissue and/or buffy coat from leukemic samples as previously described [25]. After Ficoll separation of lymphocytes (buffy coat) and granulocytes (pellet), DNA was extracted applying the Nucleospin ${ }^{\mathrm{R}}$ Blood XL kit (Machery Nagel, Dueren, Germany). Purity of cell compartments $(>95 \%)$ was confirmed by cytospin analysis. Control DNA was obtained from granulocytes or whole blood (non-leukemic cases).

LOH analysis DNA of 52 morphologically confirmed MCL and control cells were comparatively analyzed for genomic imbalances by semi-automated allelotyping applying 87 fluorescence-labeled microsatellite markers evenly distributed throughout the human genome (supplement Table 1; RER/LOH assay kit, PE Biosystems, Foster City, CA; Table 1) labeled with either FAM (blue), TET (green),

Table 1 Overview of frequently altered genomic regions in MCL and association to other genomic alterations

\begin{tabular}{ll}
\hline $\begin{array}{l}\text { Frequently altered } \\
\text { genomic loci }\end{array}$ & Associated to alterations \\
\hline $1 \mathrm{p} 13$ & $7 \mathrm{q}, 8 \mathrm{q}, 13 \mathrm{q} 13-33,15 \mathrm{q} 25,17 \mathrm{p} 13.1$ \\
$2 \mathrm{p} 23$ & $4 \mathrm{q}, 6 \mathrm{q}, 8 \mathrm{q}$ \\
$3 \mathrm{p} 25-\mathrm{pter}$ & $17 \mathrm{q} 23$ \\
$3 \mathrm{q} 22-23$ & $7 \mathrm{q}, 8 \mathrm{q}, 13 \mathrm{q} 31$ \\
$3 \mathrm{q} 27-\mathrm{q} 28$ & $7 \mathrm{q}, 8 \mathrm{q}, 13 \mathrm{q} 31$ \\
$4 \mathrm{q} 31.1$ & $1 \mathrm{p}$ \\
$6 \mathrm{p} 24$ & $19 \mathrm{p} 13,17 \mathrm{p} 13.1$ \\
$6 \mathrm{q} 23-26$ & $2 \mathrm{p}, 8 \mathrm{q}, 13 \mathrm{q}, 17 \mathrm{p} 13.2$ \\
$7 \mathrm{q}$ & $1 \mathrm{p}, 9 \mathrm{p} 21,3 \mathrm{q}$ \\
$8 \mathrm{q}$ & $15 \mathrm{q} 25,13 \mathrm{q} 13-33$ \\
$9 \mathrm{p} 21$ & $7 \mathrm{q}, 17 \mathrm{p} 13.1,17 \mathrm{p} 13.2,13 \mathrm{q} 13-33,16 \mathrm{p} 12$ \\
$9 \mathrm{q}$ & $3 \mathrm{q}, 15 \mathrm{q}, 17 \mathrm{p} 12-13,17 \mathrm{p} 13.2,17 \mathrm{p} 13.3,17 \mathrm{q} 23$ \\
$11 \mathrm{q} 14$ & $4 \mathrm{q}$ \\
$12 \mathrm{q}$ & $1 \mathrm{p}, 3 \mathrm{q}, 6 \mathrm{q}, 8 \mathrm{q}, 9 \mathrm{p} 21$ \\
$13 \mathrm{q} 13-33$ & $8 \mathrm{q}, 1 \mathrm{p}, 9 \mathrm{q}, 9 \mathrm{p} 21$ \\
$15 \mathrm{q} 25$ & $8 \mathrm{q}, 15 \mathrm{q}, 9 \mathrm{p} 21$ \\
$16 \mathrm{p} 12$ &
\end{tabular}


or HEX (yellow). PCR was performed with $25 \mathrm{ng}$ genomic template DNA in a $20 \mu \mathrm{l}$ reaction volume according to the manufacturer's protocol. After an initial AmpliTaq gold (Applied Biosystems) activation step at $95^{\circ} \mathrm{C}$ for $10 \mathrm{~min}$, 35 PCR cycles were performed at $95^{\circ} \mathrm{C}$ for $10 \mathrm{~s}, 55$ for $30 \mathrm{~s}$ and $72^{\circ} \mathrm{C}$ for $2 \mathrm{~min}$ followed by a final extension at $72^{\circ} \mathrm{C}$, $10 \mathrm{~min}$. Amplification products were pooled and analyzed on an ABIPrism310 DNA sequencer (PE Biosystems). Analysis of peak height and fragment size was performed with the Genescan Fragment Analysis and Genotyper software (PE Biosystems). Based on previous standardization experiments, allelic imbalance was diagnosed if the peak ratio of both alleles differed by more than three standard deviations between lymphoma and normal peripheral blood cells. Allelic imbalances were evaluated by calculating the ratio between the allele ratio of the healthy sample and that of the diseased sample considering a score higher than 1.35 as an amplification and lower 0.67 as loss of heterozygosity [43].

Proliferation index and p53 expression status The proliferation (Ki67) index and p53 expression were assessed by immunohistochemistry as previously described [14, 35]. P53 overexpression was defined as strong p53 staining of $>20 \%$ of tumor cell nuclei.

TP53 mutation status MCL patient samples were screened for mutations in p53 exons 5-9 by PCR-SSCP analysis coupled with direct PCR sequencing as previously described [50].

Data analysis For statistical analysis Chi-square tests, Fisher's exact $t$-test and odds ratio analysis were performed. An association was assumed significant if $p<0.05$. The
NCBI data base http://www.ncbi.nlm.nih.gov/genome/ guide/human/d and http://www.ncbi.nlm.nih.gov/entrez/ query was searched for potential candidate genes. The human (Homo sapiens) Genome Browser Gateway http:// genome.cse.ucsc.edu/cgi-bin/hgGateway was used to screen for microRNA locations.

\section{Results}

Identification of genomic imbalances In 560 out of 4,367 analyses $(12.8 \%)$ genomic imbalances were identified including 378 deletions (67.5\%) and 182 amplification $(32.5 \%)$. The median number of losses and gains per patient was 7.3 and 3.5. In all patients, at least one genomic alteration was detected, with a median number of 11 genomic imbalances per patient. Number of genomic imbalances was not significantly different in blastoid or classical MCL as well as those with low and high proliferation.

Imbalances of genomic regions The frequencies of identified genomic imbalances are summarized in Fig. 1. In 13 of 87 microsatellite markers, a significant rate $(>20 \%)$ of allelic losses were detected corresponding to nine of the 37 analyzed chromosomal arms $(24.3 \%)$. The most frequently detected allelic losses involved chromosomal bands $1 \mathrm{p} 21$ (28\%); 2p23 (20.4\%); 6q26 (20.9\%), 7q35 (20.6\%); 9q21 (42.1\%), 9q31-33 (24.2\%); 9p21 (28.6\%); 13q13-14 $(26.5 \%) ; 13 q 31-32$ (25\%), $17 \mathrm{p} 13.1 \quad(45.2 \%) ;$ TP53 (28.9\%), and 17p13.3 (50\%; Fig. 1).

A significant rate ( $>10 \%$ of patients) of allelic gains were detected in $9.7 \%$ of chromosomal bands corresponding to

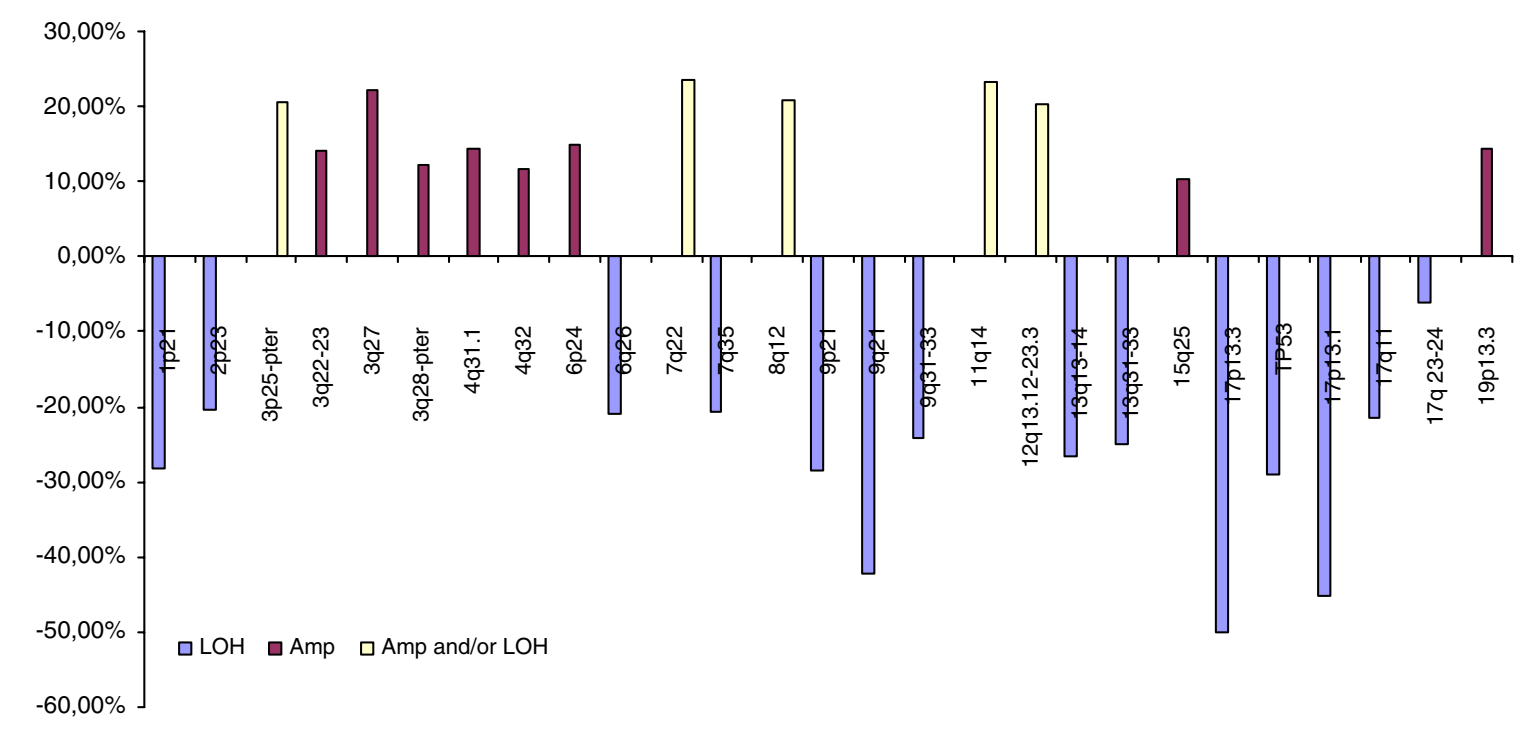

Fig. 1 Frequent genomic alterations in MCL samples 
five of 37 analyzed chromosome arms (13.5\%). Allelic gains were most frequently detected on chromosomal bands $3 \mathrm{q} 27$ (22.2\%), 4q31.1 (14.2\%), 6p24 (15\%), 19p13.3 (14.2\%; Fig. 1).

Allelic losses and/or gains of 5 additional frequently altered loci (3p25-pter, 7q22, 8q12, 11q14, 12q13-23) were identified (Fig. 1).

Morphology, proliferation index, and genetic imbalances Detailed statistical analysis (odds ratio, chi square tests) revealed a cluster of genomic alterations of chromosomal bands 1p21, 3q27, 6p24, 7q35, 9p21, 9q31-33, and 16p12 which was closely associated with a high proliferation index (Fig. 2). Alterations of 7q35 were mainly associated to alterations of loci of the proliferation cluster $(9 \mathrm{p} 21 ; 1 \mathrm{p}$; $3 q)$ but also to $17 \mathrm{p} 13.1$ (Fig. 2; Table 1). Genomic alterations of $3 \mathrm{q} 27,6 \mathrm{p} 24$, and $4 \mathrm{q} 31.1$ were significantly more frequent in samples with blastoid morphology.

p53 alterations p53 alterations, $p 53$ mutations and/or alterations in P53 protein expression, were found in $47 \%$ of analyzed samples. These alterations were directly correlated to genomic imbalances in $17 \mathrm{p} 13.1 \quad(p<0.05)$. Genomic alterations in $17 \mathrm{p} 13.1$ were highly associated to blastoid morphology and loci of the proliferation-associated cluster like 1p21, 6p24, 9p13-21, and 9q31-33 (Table 2, Fig. 3).

\section{Discussion}

MCL is characterized by the $\mathrm{t}(11 ; 14)(\mathrm{q} 13 ; \mathrm{q} 32)$ chromosomal translocation leading to constitutive overexpression of cyclinD1 [49]. However, this translocation alone is not sufficient to promote MCL development but additional genomic alterations appear to be essential for malignant transformation [30]. To identify secondary genetic alter- ations involved, several groups have applied different techniques such as cytogenetic analysis, comparative genomic hybridization or DNA microarray $[1,5,11,19$, $28,44]$. In this study, we used a comprehensive method of allelotyping for the detection of genomic gains and losses in MCL [24].

Our data confirmed previously described MCL genomic alterations. Allelic losses and gains were encountered most frequently in chromosomal bands $1 \mathrm{p} 21,9 \mathrm{p} 21,9 \mathrm{q} 21$, 13q13-14, 13q31-32, 17p13.1, and 17p13.3.

One of the most frequently altered locus in the present study (9q21; 42\%) harbors various genes involved in DNA repair and maintenance of chromosome stability, but also the B-cell-associated tyrosine kinase which was described as a potential therapeutic target by genomic and expression profiling [38]. Alterations of 9q21-q22 have recently been described as a novel marker of inferior outcome in MCL [40]. We could demonstrate a borderline association between genomic alterations of 9q21-q22 and $p 53(p=0,052)$. Such p53 mutations have been described to be associated with variant cytology and predict a poor prognosis [20]. In the present study, alterations of the $9 \mathrm{q} 21$ locus were not directly associated to proliferation, but to the proliferationassociated cluster of alterations (Table 1).

The 9p21 locus is one member of the proliferationassociated cluster, which harbors the INK4 tumor suppressor gene cluster. Inactivation of tumor suppressor genes $p 15$ (INK4b) and p16(INK4a) has previously been shown to be involved in secondary transformations of indolent lymphoma $[14],[15,17]$ and specifically in the blastoid variant of MCL $[14,37]$. Accordingly, in the present study, LOH of 9p21 was closely associated with cell proliferation but also $p 53$ alterations (Figs. 2 and 3). The previously described rare $p 16$ (INK4a) promoter methylation may represent an additional mechanism of gene-specific cell cycle dysregulation in MCL [25]. 9p21 alterations were indirectly associated to other
Fig. 2 The proliferation-associated cluster of frequent genomic alterations. Associations were determined as significant if $p<0.05$

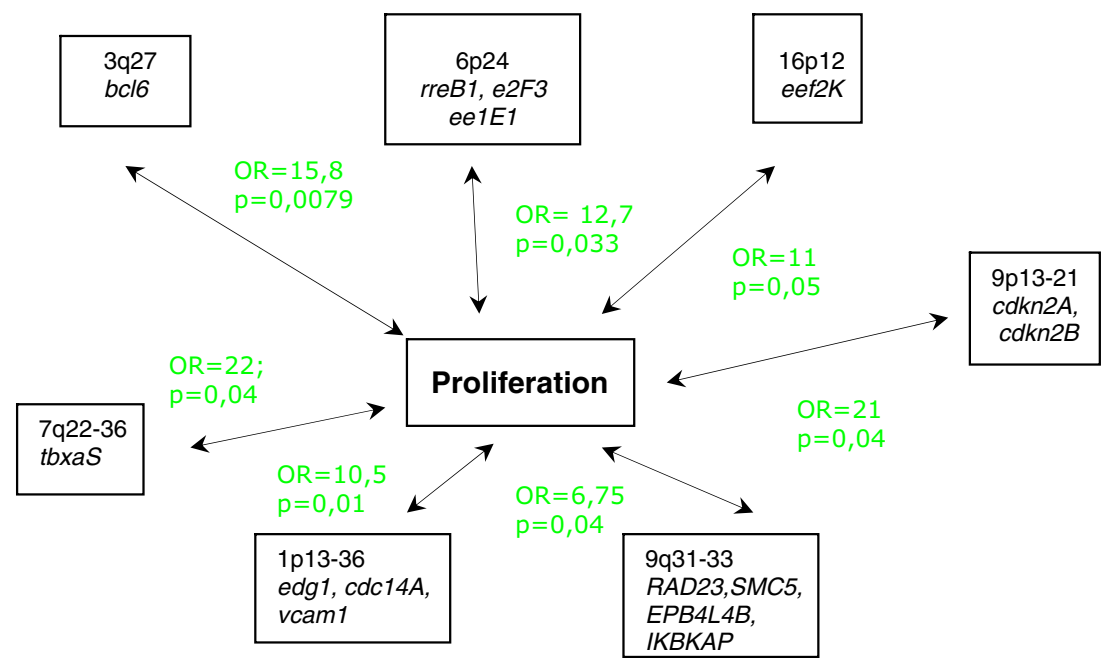


Fig. 3 The cell proliferation cluster of frequently genomic alterations in MCL. An association was determined significant if $p \leq 0.05 . p 53$ alterations include mutations in $p 53$ and alterations in $\mathrm{P} 53$ protein expression

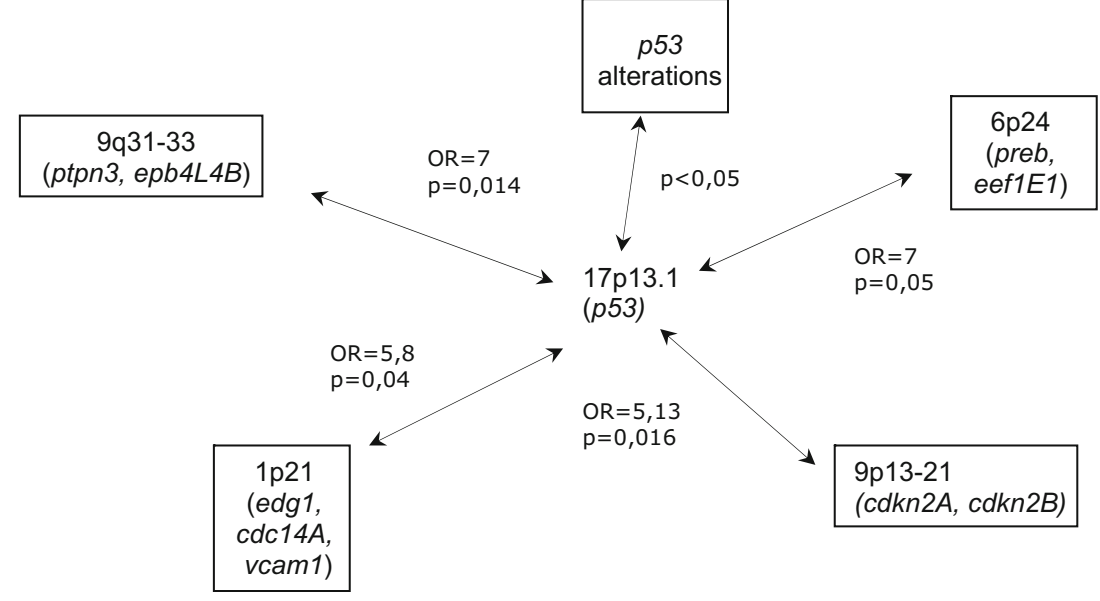

members of the proliferation cluster (Table 1). However, alterations of the genetic loci 3q27 and 1p13-36, members of the proliferation cluster, were not associated to each other and thus may represent alternative signal pathways linked to $7 \mathrm{q}$ alterations (Table 1). Other members of the proliferationassociated cluster are constituted by alterations in 9q31-33, 6 p24, and 16p12 (Fig. 2) harboring potential interesting candidate genes such as rad23, the $e 2 f$ transcription factor3, eef1E1 (eukaryotic translation elongation factor 1 epsilon), and the eeflE1 kinase.

We could also show frequent alterations (amplification and $\mathrm{LOH}$ ) in the $12 \mathrm{q} 13$ locus. This locus potentially involves the $c d k 4, m d m 2$, rarg, atf, and $c d 63$ genes [4]. Those genes were reported to be differentially expressed in MCL as compared to normal B-cell populations [22]. In addition, Hernandez et al. reported that $c d k 4$ and $m d m 2$ gene alterations mainly occur in MCL with wild-type
INK $4 a / A R F$ locus and may contribute to the higher proliferation and more aggressive behavior of the tumor [22]. However, in our series, only a tendency towards reverse correlation between 9p21 and 12q13 alterations has been detected (data not shown).

As previously described, we detected a high frequency of $\mathrm{LOH}$ in the $p 53$ locus, which has been reported as a marker of poor prognosis associated with blastoid variants of MCL [20, 21]. Accordingly, Tamaru et al. concluded that overexpression of $p 53$ and $p 27 K I P 1$ may be linked to a cellular mechanism involved in the development of the variant form of MCL [47]. Mutant $p 53$ alleles were also correlated to proliferation signature and worse overall survival in comparison to wild-type cases [20]. In line with these observations, $\mathrm{LOH}$ in $17 \mathrm{p} 13.1$ harboring $p 53$ were associated to members of the proliferation-associated cluster in our study.
Table 2 Associations between genetic alterations in $17 \mathrm{p} 13.1$ and genetic alterations of other loci

\begin{tabular}{|c|c|c|c|}
\hline $\begin{array}{l}\text { Locus/morphology (number of analyzed } \\
\text { samples) }\end{array}$ & Alterations in 17p13.1 (nr; \%) & Odds ratio & $p$ value \\
\hline \multicolumn{4}{|l|}{ 1p21(D1S206) (42) } \\
\hline $13+$ & $+(11 ; 84.6 \%)$ & 5.8 & 0.04 \\
\hline $29-$ & $-(14 ; 48 \%)$ & & \\
\hline \multicolumn{4}{|l|}{ 6p24 (D6S1574) (42) } \\
\hline $10+$ & $+(9 ; 90 \%)$ & 7 & 0.05 \\
\hline $32-$ & $-(18 ; 56 \%)$ & & \\
\hline \multicolumn{4}{|l|}{ 9p13-21 (D9S285, D9S171, D9S273) (50) } \\
\hline $20+$ & $+(17 ; 85 \%)$ & 5.13 & 0.016 \\
\hline $30-$ & $-(15 ; 50 \%)$ & & \\
\hline \multicolumn{4}{|l|}{$9 q 31-33$ (D9S1677) (37) } \\
\hline $10+$ & $+(6 ; 60 \%)$ & 6.6 & 0.014 \\
\hline $27-$ & $-(5 ; 18.5 \%)$ & & \\
\hline \multicolumn{4}{|l|}{ 17p13.2 (D17S938, D17S516) (45) } \\
\hline $23+$ & $+(14 ; 60.8 \%)$ & 15.5 & 0.014 \\
\hline $22-$ & $-(2 ; 8.3 \%)$ & & \\
\hline \multicolumn{4}{|l|}{ Morphology (33) } \\
\hline $10+$ (blastoid) & $+(6 ; 60 \%)$ & 33 & 0.01 \\
\hline $23-($ classical $)$ & $-(1 ; 4.3 \%)$ & & \\
\hline
\end{tabular}


We could also identify a distinct frequently altered chromosomal region on $17 \mathrm{p} 13.3$, with several candidate tumor suppressor genes such as tusc5, ovca2, mnt/rox, or hicl which were described to be altered in other cancers [10, 29]. Interestingly, a functional cooperation between hicl and p53 has been described. Hicl was involved in certain feedback regulation of $p 53$ by histone deacetylase sirt1 $[7,8]$.

The frequently altered loci of chromosomal arm 13q31-33 harbor miRNA, small non-coding RNAs thought to be involved in physiologic and developmental processes by negatively regulating expression of target genes (http://micro rna.sanger.ac.uk/). Ota et al. identified a new gene C13orf 25 in 13q31-32 which contains seven mature microRNAs in its untranslated region [34]. Additionally, O'Donnel et al. showed that $c-m y c$ activates expression of a cluster of six miRNAs on chromosome 13. Furthermore, expression of $e 2 f 1$, another target of c-myc promoting cell cycle, is negatively regulated by two miRNAs of this cluster [33].

Another important tumor suppressor region on chromosomal band 13q14, deleted in up to $70 \%$ of MCL, has been suggested relevant for the pathogenesis of mantle cell lymphomas [14, 46]. In CLL deletions of 13q13-14 have been reported to be strongly associated clinical outcome [3, 12]. Accordingly, genetic alterations of $13 \mathrm{q} 14$ have been associated with inferior overall survival in MCL [28]. In this region, miR-15a and miR-16a have been reported to be frequently deleted and/or down-regulated in CLL patients [6]. Expression of miR-15a and miR-16a has been inversely correlated to BCL2 expression in CLL and characterized as negative regulator of $b c l 2$ at posttranscriptional levels [9].

In summary, most of the frequent genomic alterations demonstrated in MCL in the present study are associated with dysregulation of the cell cycle machinery and interfere with the cellular response to DNA damage. Systematic genotyping identified a proliferation-associated cluster involving 1p21, 6p24,9p21, and 9q31 loci. These results support and complement the proliferation signature previously defined by RNA expression profiling [18, 39]. Additional studies of this genomic region will provide further insights into the molecular pathogenesis of MCL.

\section{References}

1. Allen JE, Hough RE, Goepel JR, Bottomley S, Wilson GA, Alcock HE et al (2002) Identification of novel regions of amplification and deletion within mantle cell lymphoma DNA by comparative genomic hybridization. $\mathrm{Br} \mathrm{J}$ Haematol 116 (2):291-298 doi:10.1046/j.1365-2141.2002.03260.x

2. Banks PM, Chan J, Cleary ML, Delsol G, De Wolf-Peeters C, Gatter K et al (1992) Mantle cell lymphoma. A proposal for unification of morphologic, immunologic, and molecular data. Am J Surg Pathol 16(7):637-640 doi:10.1097/00000478199207000-00001
3. Bastard C, Raux G, Fruchart C, Parmentier F, Vaur D, Penther D, Troussard X, Nagib D, Lepretre S, Tosi M, Frebourg T, Tilly H (2007) Comparison of a quantitative PCR method with FISH for the assessment of the four aneuploidies commonly evaluated in CLL patients. Leukemia 21(7):1460-1463 doi:10.1038/sj. leu. 2404727

4. Bea S, Ribas M, Hernandez JM, Bosch F, Pinyol M, Hernandez L et al (1999) Increased number of chromosomal imbalances and high-level DNA amplifications in mantle cell lymphoma are associated with blastoid variants. Blood 93(12):4365-4374

5. Bentz M, Plesch A, Bullinger L, Stilgenbauer S, Ott G, MüllerHermelink HK, Baudis M et al $(2000) \mathrm{t}(11 ; 14)$-positive mantle cell lymphomas exhibit complex karyotypes and share similarities with B-cell chronic lymphocytic leukemia. Genes Chromosomes Cancer 27(3):285-294 doi:10.1002/(SICI)1098-2264(200003) 27:3<285::AID-GCC9>3.0.CO;2-M

6. Calin GA, Dumitru CD, Shimizu M, Bichi R, Zupo S, Noch E et al (2002) Frequent deletions and down-regulation of micro-RNA genes miR15 and miR16 at 13q14 in chronic lymphocytic leukemia. Proc Natl Acad Sci USA 99(24):15524-15529 doi:10.1073/pnas.242606799

7. Chen WY, Wang DH, Yen RC, Luo J, Gu W, Baylin SB (2005) Tumor suppressor HIC1 directly regulates SIRT1 to modulate p53-dependent DNA-damage responses. Cell 123(3):437-448 doi:10.1016/j.cell.2005.08.011

8. Chopin V, Leprince D (2006) Chromosome arm 17p13.3: could HIC1 be the one? Med Sci (Paris) 22(1):54-61

9. Cimmino A, Calin GA, Fabbri M, Iorio MV, Ferracin M, Shimizu $\mathrm{M}$ et al (2005) miR-15 and miR-16 induce apoptosis by targeting BCL2. Proc Natl Acad Sci USA 102(39):13944-13949 doi:10.1073/pnas.0506654102

10. Cvekl A Jr, Zavadil J, Birshtein BK, Grotzer MA, Cvekl A (2004) Analysis of transcripts from $17 \mathrm{p} 13.3$ in medulloblastoma suggests ROX/MNT as a potential tumour suppressor gene. Eur J Cancer 40(16):2525-2532 doi:10.1016/j.ejca.2004.08.005

11. de Leeuw RJ, Davies JJ, Rosenwald A, Bebb G, Gascoyne RD, Dyer MJ et al (2004) Comprehensive whole genome array CGH profiling of mantle cell lymphoma model genomes. Hum Mol Genet 13(17):1827-1837 doi:10.1093/hmg/ddh195

12. Doehner H, Stilgenbauer S, Benner A, Leupolt E, Kröber A, Bullinger L, Doehner K, Bentz M, Lichter P (2000) Genomic aberrations and survival in chronic lymphocytic leukemia. N Engl J Med 343(26):1910-1916 doi:10.1056/NEJM200012283432602

13. Dreyling M, Bergsagel PL, Gordon LI, Cotter FE (2006) Mantle cell lymphoma and other $\mathrm{t}(11 ; 14)$ disorders: How biology can drive therapy. ASCO Educational book, 476-484

14. Dreyling MH, Bullinger L, Ott G, Stilgenbauer S, MullerHermelink HK, Bentz M et al (1997) Alterations of the cyclin D1/p16-pRB pathway in mantle cell lymphoma. Cancer Res 57 (20):4608-4614

15. Dreyling MH, Roulston D, Bohlander SK, Vardiman J, Olopade OI (1998) Codeletion of CDKN2 and MTAP genes in a subset of non-Hodgkin's lymphoma may be associated with histologic transformation from low-grade to diffuse large-cell lymphoma. Genes Chromosomes Cancer 22(1):72-78 doi:10.1002/(SICI) 1098-2264(199805)22:1<72::AID-GCC10>3.0.CO;2-K

16. Ek S, Bjorck E, Porwit-MacDonald A, Nordenskjold M, Borrebaeck CA (2004) Increased expression of Ki-67 in mantle cell lymphoma is associated with de-regulation of several cell cycle regulatory components, as identified by global gene expression analysis. Haematologica 89(6):686-695

17. Elenitoba-Johnson KS, Gascoyne RD, Lim MS, Chhanabai M, Jaffe ES, Raffeld M (1998) Homozygous deletions at chromosome 9p21 involving p16 and p15 are associated with histologic progression in follicle center lymphoma. Blood 91(12):4677-4685 
18. Fernandez V, Hartmann E, Ott G, Campo E, Rosenwald A (2005) Pathogenesis of mantle-cell lymphoma: all oncogenic roads lead to dysregulation of cell cycle and DNA damage response pathways. J Clin Oncol 23(26):6364-6369 doi:10.1200/ JCO.2005.05.019

19. Flordal TE, Ichimura K, Collins VP, Walsh SH, Barbany G, Hagberg A et al (2007) Detailed assessment of copy number alterations revealing homozygous deletions in $1 p$ and $13 q$ in mantle cell lymphoma. Leuk Res 31(9):1219-1230 doi:10.1016/j. leukres.2006.10.022

20. Greiner TC, Dasgupta C, Ho VV, Weisenburger DD, Smith LM, Lynch JC et al (2006) Mutation and genomic deletion status of ataxia telangiectasia mutated (ATM) and p53 confer specific gene expression profiles in mantle cell lymphoma. Proc Natl Acad Sci USA 103(7):2352-2357 doi:10.1073/pnas.0510441103

21. Hernandez L, Fest T, Cazorla M, Teruya-Feldstein J, Bosch F, Peinado MA et al (1996) p53 gene mutations and protein overexpression are associated with aggressive variants of mantle cell lymphomas. Blood 87(8):3351-3359

22. Hernandez L, Bea S, Pinyol M, Ott G, Katzenberger T, Rosenwald A et al (2005) CDK4 and MDM2 gene alterations mainly occur in highly proliferative and aggressive mantle cell lymphomas with wild-type INK4a/ARF locus. Cancer Res 65(6):2199-2206 doi:10.1158/0008-5472.CAN-04-1526

23. Hinds PW, Dowdy SF, Eaton EN, Arnold A, Weinberg RA (1994) Function of a human cyclin gene as an oncogene. Proc Natl Acad Sci USA 91(2):709-713 doi:10.1073/pnas.91.2.709

24. Hovig E, Smith-Sorensen B, Uitterlinden AG, Borresen AL (1992) Detection of DNA variation in cancer. Pharmacogenetics 2(6):317-328 doi:10.1097/00008571-199212000-00011

25. Hutter G, Scheubner M, Zimmermann Y, Kalla J, Katzenberger T, Hubler K et al (2006) Differential effect of epigenetic alterations and genomic deletions of CDK inhibitors [p16(INK4a), p15 (INK4b), p14(ARF)] in mantle cell lymphoma. Genes Chromosomes Cancer 45(2):203-210 doi:10.1002/gcc.20277

26. Jaffe ES, Harris NL, Stein H et al (2001) World Health Organization classification of tumors: pathology and genetics of tumors of haemotopoetic and lymphoid tissues. IARC, Lyon, France

27. Katzenberger T, Petzoldt C, Höller S, Mäder U, Kalla J, Adam P, Ott MM, Müller-Hermelink HK, Rosenwald A, Ott G (2006) The Ki67 proliferation index is a quantitative indicator of clinical risk in mantle cell lymphoma. Blood 107(8):3407 doi:10.1182/blood2005-10-4079

28. Kohlhammer H, Schwaenen C, Wessendorf S, Holzmann K, Kestler HA, Kienle D et al (2004) Genomic DNA-chip hybridization in $\mathrm{t}(11 ; 14)$-positive mantle cell lymphomas shows a high frequency of aberrations and allows a refined characterization of consensus regions. Blood 104(3):795-801 doi:10.1182/blood2003-12-4175

29. Konishi H, Sugiyama M, Mizuno K, Saito H, Yatabe Y, Takahashi $\mathrm{T}$ et al (2003) Detailed characterization of a homozygously deleted region corresponding to a candidate tumor suppressor locus at distal $17 \mathrm{p} 13.3$ in human lung cancer. Oncogene 22(12):18921905 doi: $10.1038 /$ sj.onc. 1206304

30. Lovec H, Grzeschiczek A, Kowalski MB, Moroy T (1994) Cyclin D1/bcl-1 cooperates with myc genes in the generation of B-cell lymphoma in transgenic mice. EMBO J 13(15):3487-3495

31. Monni O, Oinonen R, Elonen E, Franssila K, Teerenhovi L, Joensuu $H$ et al (1998) Gain of 3q and deletion of 11q22 are frequent aberrations in mantle cell lymphoma. Genes Chromosomes Cancer 21(4):298-307 doi:10.1002/(SICI)1098-2264 (199804)21:4<298::AID-GCC3>3.0.CO;2-U

32. Nagy B, Lundan T, Larramendy ML, Aalto Y, Zhu Y, Niini T et al (2003) Abnormal expression of apoptosis-related genes in haematological malignancies: overexpression of MYC is poor prognostic sign in mantle cell lymphoma. $\mathrm{Br} \mathrm{J}$ Haematol 120 (3):434-441 doi:10.1046/j.1365-2141.2003.04121.x

33. O'Donnell KA, Wentzel EA, Zeller KI, Dang CV, Mendell JT (2005) c-Myc-regulated microRNAs modulate E2F1 expression. Nature 435(7043):839-843 doi:10.1038/nature03677

34. Ota A, Tagawa H, Karnan S, Tsuzuki S, Karpas A, Kira S et al (2004) Identification and characterization of a novel gene, C13orf25, as a target for 13q31-q32 amplification in malignant lymphoma. Cancer Res 64(9):3087-3095 doi:10.1158/0008-5472. CAN-03-3773

35. Ott G, Kalla J, Ott MM, Schryen B, Katzenberger T, Muller JG, Muller-Hermelink HK (1997) Blastoid variants of mantle cell lymphoma: frequent bcl-1 rearrangements at the major translocation cluster region and tetraploid chromosome clones. Blood 89 (4):1421-1429

36. Pinyol M, Hernandez L, Cazorla M, Balbin M, Jares P, Fernandez PL et al (1997) Deletions and loss of expression of p16INK4a and p21Wafl genes are associated with aggressive variants of mantle cell lymphomas. Blood 89(1):272-280

37. Pinyol M, Cobo F, Bea S, Jares P, Nayach I, Fernandez PL et al (1998) p16(INK4a) gene inactivation by deletions, mutations, and hypermethylation is associated with transformed and aggressive variants of non-Hodgkin's lymphomas. Blood 91(8):2977-2984

38. Rinaldi A, Kwee I, Taborelli M, Largo C, Uccella S, Martin V et al (2006) Genomic and expression profiling identifies the B-cell associated tyrosine kinase Syk as a possible therapeutic target in mantle cell lymphoma. Haematol 132(3):303-316 doi:10.1111/ j.1365-2141.2005.05883.x

39. Rosenwald A, Wright G, Wiestner A, Chan WC, Connors JM, Campo E et al (2003) The proliferation gene expression signature is a quantitative integrator of oncogenic events that predicts survival in mantle cell lymphoma. Cancer Cell 3(2):185-197 doi:10.1016/S1535-6108(03)00028-X

40. Rubio-Moscardo F, Climent J, Siebert R, Piris MA, Martin-Subero JI, Nielander I et al (2005) Mantle-cell lymphoma genotypes identified with $\mathrm{CGH}$ to $\mathrm{BAC}$ microarrays define a leukemic subgroup of disease and predict patient outcome. Blood 105 (11):4445-4454 doi:10.1182/blood-2004-10-3907

41. Salaverria I, Zettl A, Beà S, Moreno V, Valls J, Hartmann E et al (2007) Specific secondary genetic alterations in mantle cell lymphoma provide prognostic information independent of the gene expression-based proliferation signature. J Clin Oncol 25 (10):1216-1222 doi:10.1200/JCO.2006.08.4251

42. Schaffner C, Idler I, Stilgenbauer S, Dohner H, Lichter P (2000) Mantle cell lymphoma is characterized by inactivation of the ATM gene. Proc Natl Acad Sci USA 97(6):2773-2778 doi:10.1073/ pnas.050400997

43. Scheubner M, Huebler K, Hutter G, Ott G, Hiddemann W, Dreyling MH (2002) Oncogenic Hirarchy of Genomic Alterations in MCL: p16Ink4a Deletions and 13q14 alterations suggest a common mechanism of cell cycle alteration. 44th Annual Meeting of the American Society of Hematology, Philadelphia. Blood 100:565a

44. Schrader C, Janssen D, Klapper W, Siebmann JU, Meusers P, Brittinger G, Kneba M et al (2005) Minichromosome maintenance protein 6 , a proliferation marker superior to $\mathrm{Ki}-67$ and independent predictor of survival in patients with mantle cell lymphoma. Br J Cancer 93(8):939-945 doi:10.1038/sj.bjc.6602795

45. Stilgenbauer S, Schaffner C, Winkler D, Ott G, Leupolt E, Bentz $M$ et al (2000) The ATM gene in the pathogenesis of mantle-cell lymphoma. Ann Oncol 11(Suppl 1):127-130 doi:10.1023/ A:1008315003377

46. Stilgenbauer S, Nickolenko J, Wilhelm J, Wolf S, Weitz S, Dohner $\mathrm{K}$ et al (1998) Expressed sequences as candidates for a novel tumor suppressor gene at band $13 \mathrm{q} 14$ in B-cell chronic lymphocytic 
leukemia and mantle cell lymphoma. Oncogene 16(14):1891-1897 doi:10.1038/sj.onc.1201764

47. Tamaru JI, Kawana H, Takahashi Y, Takahashi N, Isobe K, Hirai A et al (1999) Expression of cell cycle regulating proteins in an unusual transformation of mantle cell lymphoma. Leuk Lymphoma 36(1-2):128-137

48. Tiemann M, Schrader C, Klapper W, Dreyling MH, Campo E, Norton A et al (2005) European MCL Network. Histopathology, cell proliferation indices and clinical outcome in 304 patients with mantle cell lymphoma (MCL): a clinicopathological study from the European MCL Network. Br J Haematol 131(1):29-38 doi:10.1111/j.1365-2141.2005.05716.x

49. Tsujimoto Y, Finger LR, Yunis J, Nowell PC, Croce CM (1984) Cloning of the chromosome breakpoint of neoplastic B cells with the $\mathrm{t}(14 ; 18)$ chromosome translocation. Science 226(4678):10971099 doi:10.1126/science. 6093263

50. Volkmann M, Schiff JH, Hajjar Y, Otto G, Stilgenbauer F, Fiehn W et al (2001) Loss of CD95 expression is linked to most but not all p53 mutants in European hepatocellular carcinoma. J Mol Med 79(10):594-600 doi:10.1007/s001090100244 